\title{
The WAIS Divide ice core: Progress and plans
}

JefF SEVERINGHaUs

Scripps Institution of Oceanography, University of California, San Diego, USA; jseveringhaus@ucsd.edu

\section{Introduction}

For over 20 years, the international glaciological community has recognized the need for a deep ice core from the flow divide in central West Antarctica. This would provide the first Southern Hemisphere climate record of comparable resolution and duration to the Greenland ice cores, which have revolutionized our notion of past climate stability. It would also test models of West Antarctic lce Sheet (WAIS) history and stability, a major concern for future sea level. The WAISCORES initiative was launched by the U.S. National Science Foundation in the 1990s to realize these goals through the drilling of two deep cores. The first was a deep core at the coastal site Siple Dome (Brook et al., 2005; Severinghaus et al., 2003; Taylor et al., 2004), which is now complete, and the second is a deep core at the ice flow divide in the center of the WAIS, known as the WAIS Divide core (Fig. 1). This article discusses the current state of the WAIS Divide project, the scientific questions to be addressed, and future plans.

The WAIS Divide ice core drilling

Site selection was recently completed for the WAIS Divide project (see box). During the 2005-2006 season just finished, a camp was established, shallow cores were retrieved, and firn air sampling was conducted. A new deep drill (called the DISC drill) has been constructed for the WAIS Divide project and will be tested at Greenland summit in summer 2006. This test will focus on optimizing core quality in the brittle ice zone, and will reach a depth of $600 \mathrm{~m}$. The 2006-2007 season will be devoted to drill setup at the WAIS Divide site, and deep drilling will begin in earnest in the 2007-2008 season.

The chosen site is an almost exact analog to GISP2 in Greenland in terms of temperature, accumulation rate, gas age-ice age difference, and other variables. The site is $\sim 24 \mathrm{~km}$ downslope of the flow divide, similar to GISP2, to insure that no divide

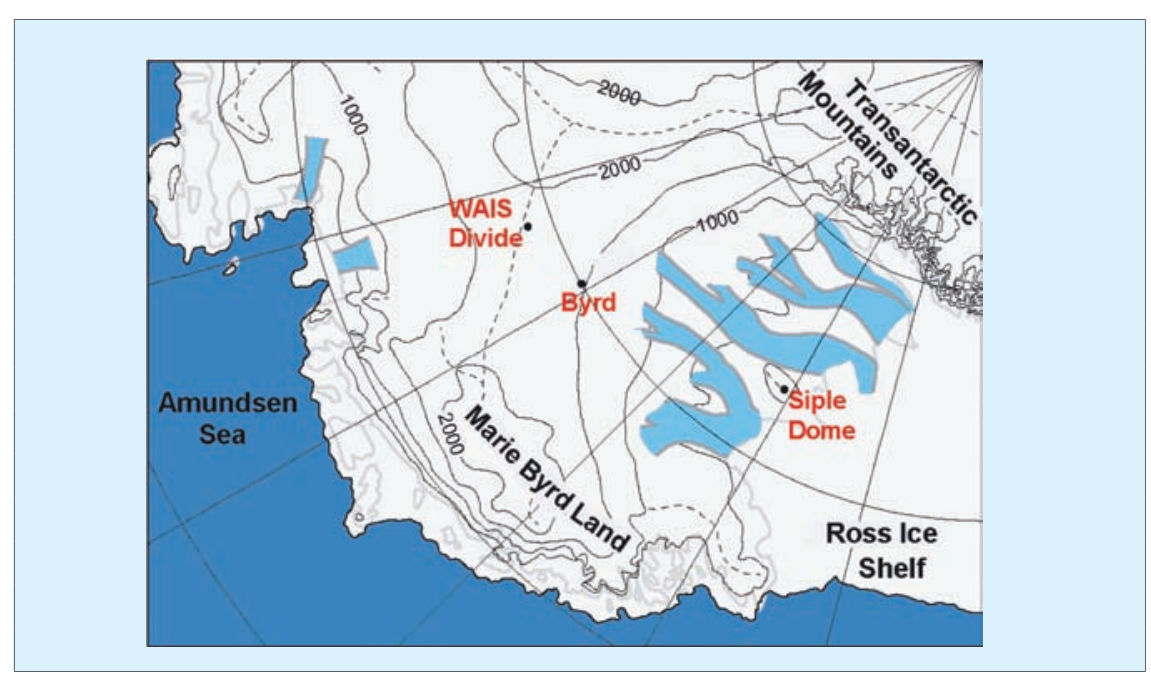

Fig. 1: Map showing locations of the existing Byrd and Siple Dome ice cores, and the planned WAIS Divide ice core.

migration has compromised the stratigraphy. Because this is the leeward side relative to the prevailing storm track, the accumulation rate at the site is substantially less than at the divide itself. This has the advantage of making the Holocene section of the core more compact, and older sections expanded, because deeper ice originated closer to the divide.

\section{Objectives}

Like GISP2, WAIS Divide is expected to yield a high-resolution record of temperature and atmospheric methane during the millennial-scale (Dansgaard-Oeschger) oscillations of the last glacial period. Because of the small age difference between the gases and the enclosing ice, a decadal-precision chronology relative to Greenland is expected, using methane and air ${ }^{18} \mathrm{O}$ as interhemispheric time markers. This will allow stringent tests of the bipolar see-saw hypothesis; that Atlantic ocean circulation changes caused the apparent asynchrony of Greenland and Antarctic climate records at millennial time scales.

One important difference from GISP2 is that an excellent atmospheric $\mathrm{CO}_{2}$ record is expected to be obtained because Antarctic ice has an order of magnitude less dust than Greenland ice. This will allow, for the first time, precise comparison of the relative timing of rapid variations in atmospheric methane and $\mathrm{CO}_{2}$ during the Dansgaard-Oeschger events. Atmospheric $\mathrm{CO}_{2}$ is known to respond quickly to changes in sea surface temperature, so the precise timing may shed light on the mechanism of these events. Many other gases and their isotopes will be measured at unprecedented precision and resolution $\left({ }^{13} \mathrm{CH}^{4}, \mathrm{~N}_{2} \mathrm{O}\right.$, $\mathrm{CH}_{3} \mathrm{Cl}, \mathrm{CH}_{3} \mathrm{Br} ;{ }^{15} \mathrm{~N}$ of $\mathrm{N}_{2} \cdot{ }^{18} \mathrm{O}$ and ${ }^{17} \mathrm{O}$ of $\mathrm{O}_{2},{ }^{40} \mathrm{Ar} /{ }^{36} \mathrm{Ar}, \mathrm{Kr} / \mathrm{N}_{2}, \mathrm{Xe} / \mathrm{N}_{2}$ among others). Overall the WAIS Divide core is expected to produce the best gas records of the past $100 \mathrm{kyr}$ yet obtained.

\section{Project facts}

Project: WAIS

Contact: Kendrick Taylor (Desert Research Institute, University of Nevada), kendrick.taylor@dri.edu

Steering committee: Richard Alley (Penn State), Ed Brook (Oregon State University), Jeff Severinghaus (Scripps Institution of Oceanography), Jim White (INSTAAR, University of Colorado)

Funding: NSF

Where: West Antarctic Ice Sheets (WAIS divide: $79.468^{\circ} \mathrm{S}, 112.086^{\circ} \mathrm{W}$, altitude $1765 \mathrm{~m}$, ice thickness $3465 \mathrm{~m}$

When: 2006-2011

What: Deep ice core covering approx. one glacial cycle

Web page: www.dri.edu/People/kendrick/ WDSprojmain.htm http://igloo.gsfc.nasa.gov/wais/ http://waiscores.dri.edu/ 
As in Greenland, the high accumulation rate and great ice thickness will permit high-confidence borehole thermometry-based temperature estimates for the past glacial period. Other Antarctic borehole thermometry efforts have been stymied by the low accumulation rate. WAIS Divide should provide the first reliable direct temperature estimate of the last glacial maximum in Antarctica. Other borehole logging (optical, sonic) will place unique constraints on ice deformation, which combined with accurate surface temperature history, timescale, and accumulation rate, will make a potent synergy for glaciological modeling of the history of the WAIS. This effort will address questions about the stability of this marine-based ice sheet, which would raise sea level $5 \mathrm{~m}$ if melted.

\section{Wider perspectives of the WAIS project}

International collaboration figures prominently in the WAIS Divide ef- fort. WAIS Divide is under the umbrella of the recently established International Partnerships for Ice Coring Science (IPICS), although its planning long predates IPICS. WAIS Divide is one of the first elements to get underway in the IPICS 40,000 Year Network, which will map spatial variation at the regional scale in order to better understand the dynamics of the last deglaciation (see Brook, this issue). The importance of spatial differences between cores within Antarctica has been highlighted recently by the Siple Dome record (Taylor et al., 2004). Improved understanding of regional variations in climate during the past $100 \mathrm{kyr}$ will help separate global from regional signals.

International collaboration has already greatly aided the DISC deep drill development, and it is anticipated that international partnerships on WAIS Divide drilling and science will continue at a heightened pace in the context of the International Polar
Year (2007-2008). Bottom-up, individual investigator-driven international collaborations on WAIS Divide are highly encouraged, although no formal, top-down structure for collaboration has been imposed.

\section{REFERENCES}

Brook, E.J., White, J.W.C., Schilla, A.S.M., Bender, M.L., Barnett, B., Severinghaus, J.P., Taylor, K.C., Alley, R.B., Steig, E.J., 2005: Timing of millennialscale climate change at Siple Dome, West Antarctica, during the last glacial period, Quaternary Science Reviews, 24: 1333-1343.

Taylor, K.C., White, J.W.C. Severinghaus, J.P., Brook, E.J., Mayewski, P.A., Alley, R.B., Steig, E.J., Spencer, M.K., Meyerson, E., Meese, D.A., Lamorey, G.W., Grachev, A., Gow, A.J. and Barnett, B.A., 2004: Abrupt climate change around $22 \mathrm{ka}$ on the Siple Coast of Antarctica, Quat. Sci. Rev., 23: 7-15. Severinghaus, J.P., Grachev, A., Luz, B., and Caillon, N., A, 2003: method for precise measurement of argon 40/36 and krypton/argon ratios in trapped air in polar ice with applications to past firn thickness and abrupt climate change in Greenland and at Siple Dome, Antarctica, Geochim. Cosmochim. Acta, 67: 325-343.

\section{International Trans Antarctic Scientific Expedition (ITASE)}

\section{Paul Andrew Mayewski}

Climate Change Institute, University of Maine, Orono, USA; paul.mayewski@maine.edu

\section{Introduction}

ITASE has as its primary aim the collection and interpretation of a continent-wide array of environmental parameters (Fig. 1), assembled through the coordinated efforts of scientists from 20 nations. ITASE offers the groundbased opportunities of traditional style traverse travel, coupled with the modern technology of GPS, crevasse detecting radar, satellite communications and multi-disciplinary research (Fig. 2). By operating predominantly in the mode of an oversnow traverse, ITASE offers scientists the opportunity to experience the dynamic range of the Antarctic environment. The combination of disciplines represented by ITASE provides a unique, multi-dimensional ( $x, y$, $z$ and time) view of the ice sheet and its history. As of 2004, ITASE has completed $>20,000 \mathrm{~km}$ of snow radar, recovered more than $240 \mathrm{firn} / \mathrm{ice}$ cores (total depth

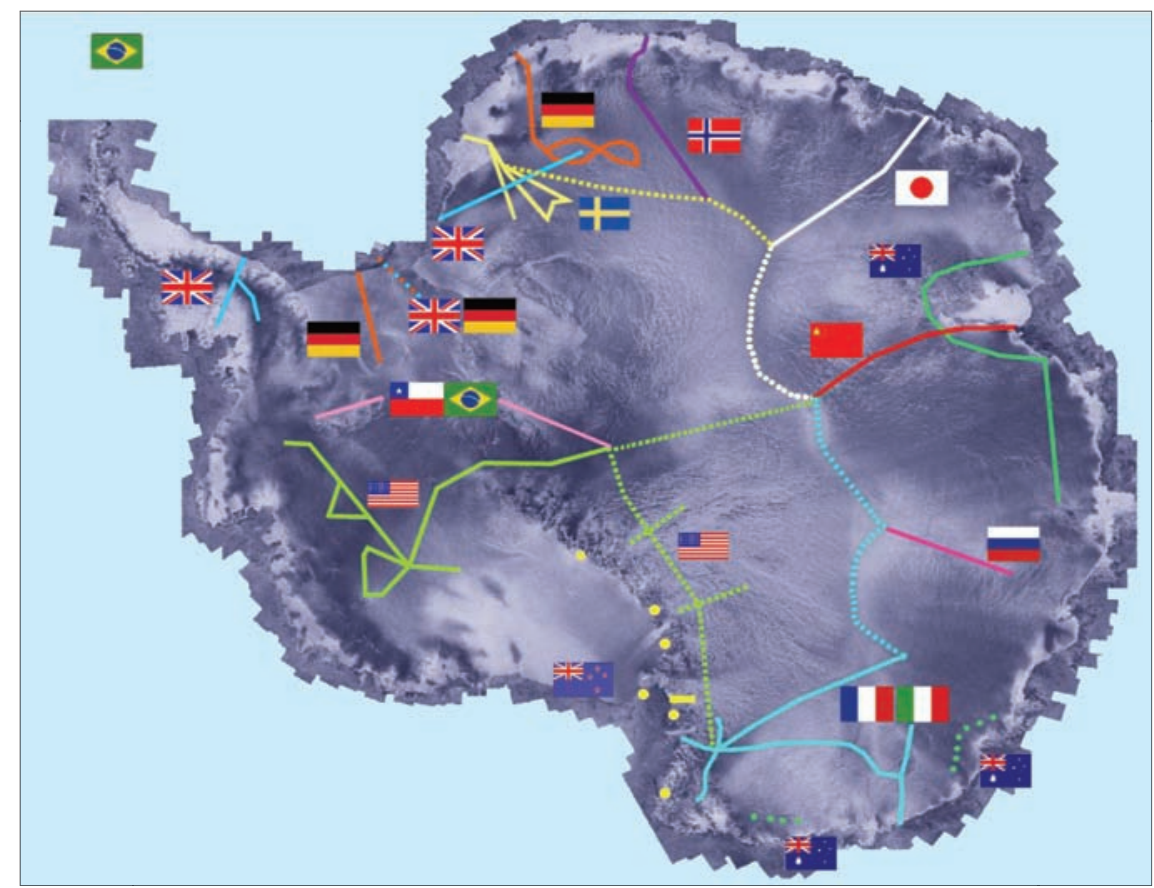

Fig. 1: ITASE national traverse routes superimposed on RADARSAT image. Solid lines represent completed traverses, dashed represent proposed or planned traverses.

$7000 \mathrm{~m})$, remotely penetrated to $\sim 4000 \mathrm{~m}$ into the ice sheet, and sampled the atmosphere to heights of $>20 \mathrm{~km}$.

\section{Results}

Although full-scale reconstructions of past climate over Antarctica have yet to be finalized, 